\title{
The role of nicotine in the pathogenesis of atherosclerosis
}

\author{
Ji-Eun Lee and John P. Cooke
}

\section{Pathogenesis of tobacco-related vascular disease}

Smoking is a major preventable risk factor for atherosclerosis. Exposure to cigarette smoke activates a number of mechanisms predisposing to atherosclerosis, including thrombosis, insulin resistance and dyslipidemia, vascular inflammation, abnormal vascular growth and angiogenesis, as well as loss of endothelial homeostatic and regenerative functions ${ }^{1-3}$. The pathophysiologic mechanisms by which tobacco smoke accelerates vascular disease are manifold and complex, in part because the smoke contains over 4000 different chemicals ${ }^{4}$. Of these, the polycyclic aromatic hydrocarbons, oxidizing agents, particulate matter, and nicotine, have been identified as potential contributing factors to atherogenesis. In addition to its role as the habituating agent in tobacco, nicotine also accelerates vascular disease. By inducing the release of catecholamines, nicotine increases heart rate and blood pressure. These adverse hemodynamic effects are associated with progression of atherosclerosis. Furthermore, nicotine-induced catecholamine release increases platelet aggregability ${ }^{3}$. Platelets contribute to the growth of plaque through the accretion of thrombus, as well as through the release of growth factors (such as platelet derived relaxing factor) that induce vascular smooth muscle cell proliferation. In addition to these actions mediated by activation of the sympathetic nervous system, nicotine has direct actions on the cellular elements participating in plaque formation.

\section{Nicotine signaling in the vessel wall}

The effects of nicotine on cells within the vessel wall are mediated by cholinergic receptors. There are two major types of cholinergic receptors, the muscarinic and the nicotinic ${ }^{5}$. Whereas acetylcholine stimulates both receptor types, nicotine preferentially stimulates the nicotinic receptor. The muscarinic receptors are 7-transmembrane spanning G protein-gated receptors. By contrast, the nicotinic acetylcholine receptors (nAChRs) are each composed of 5 subunits, arranged in a barrel-like configuration to form a channel in the cell membrane. Activation of the nAChRs by endogenous acetylcholine, or exogenous nicotine, increases permeability of these ligand-gated channels to cations. There are 16 different isoforms (a1$a 10, \beta 1-\beta 4, \delta, \gamma$. and $\varepsilon$ ) of the subunits, which form homomeric or heteromeric channels. The combinatorial association of various $\alpha-$ and $\beta$ - subunits result in functionally diverse nAChR subtypes that have different ligand affinity, cation permeability, and signaling 6,7 .

\footnotetext{
(C) 2011 Elsevier Ireland Ltd. All rights reserved.

Correspondence to: John P. Cooke, MD PhD, Professor of Medicine and Associate Director, Stanford Cardiovascular Institute, john.cooke@stanford.edu.

Disclosures

Dr. Cooke is an inventor on Stanford University patents related to therapeutic modulation of angiogenesis by agonists or inhibitors of the nACh receptors.

Publisher's Disclaimer: This is a PDF file of an unedited manuscript that has been accepted for publication. As a service to our customers we are providing this early version of the manuscript. The manuscript will undergo copyediting, typesetting, and review of the resulting proof before it is published in its final citable form. Please note that during the production process errors may be discovered which could affect the content, and all legal disclaimers that apply to the journal pertain.
} 
The nAChRs were first identified in excitable cells, but later were identified in many other cell types including vascular ${ }^{8-11}$ and immune cells ${ }^{12}$.

\section{A new role for the "muscle type" nAChR in atherosclerosis}

The "muscle-type" nAChR, first found in the neuromuscular junction of skeletal muscle, consists of the specific assembly of five polypeptide subunits $(\alpha 1, \beta 1, \delta$, and $\varepsilon$ in a 2:1:1:1 ratio). These subunits have since been described in other cell types, including endothelial cells ${ }^{13}$. In this issue of Atherosclerosis, Zhang and colleagues provide evidence that the muscle-type nAChR may play a direct role in regulating vascular smooth muscle cell proliferation and migration. They first observed that the expression of the a 1 subunit was increased 4-fold in the aortae of ApoE deficient mice fed a Western diet (by comparison to the aortae from mice fed normal chow), and was localized in vascular smooth muscle cells and some macrophages. They did not determine if the expression of the other subunits of the classical "muscle-type" nAChR was increased. However, it is known that silencing of the a 1 subunit abrogates the function of the muscle type nAChR. Accordingly, to determine if the increased expression of the a 1 subunit was of pathophysiological importance, they used a hydrodynamic approach to introduce hairpin $\mathrm{nAChR}$ a 1 -siRNA into the abdominal aorta in vivo. Their approach provided for a significant and sustained (16 weeks) silencing of the subunit in the aorta. Downregulation of the a 1 subunit was associated with a dramatic reduction (by $80 \%$ ) in the atherosclerotic lesion area in the abdominal aorta.

\section{Effect of a1-silencing on plaque cells and paracrine factors}

During the development of the atherosclerotic lesion, proliferating vascular smooth muscle cells (vsmc; or a vsmc progenitor) migrate into the intima and undergo phenotypic modulation into myofibroblasts and osteoblast-like cells. There they elaborate extracellular matrix (collagen and osteopontin), and even take up lipid to resemble macrophage-derived foam cells. In this study, silencing of the a 1 subunit was associated with an $80 \%$ reduction in myofibroblasts in the lesion, and a reduction in expression of TGF $\beta$, a vsmc mitogen. Furthermore, in the aortic root, quantification of Masson stained or von Kosa stained sections revealed that silencing of the a 1 subunit was associated with a reduction in the extracellular matrix accumulation (collagen and osteopontin) and an attenuation of calcification. These findings are consistent with the authors' hypothesis that activation of the "muscle-type" nAChR induces the proliferation and migration of vascular smooth muscle cells into the intima, mediated in part by TGF $\beta$.

In addition, immunohistochemical studies and Western blot analyses indicated that a 1 silencing was associated with a significant reduction in immune cells in the aortic wall. It is not clear if the effect on macrophage accumulation was due to a direct effect of the a 1siRNA on macrophages in the vessel wall. Another possibility is that the a1-silencing reduced nAChR-mediated activation of other plaque cells, inhibiting their elaboration of adhesion molecules or chemokines involved in macrophage accumulation.

In this regard, immunohistochemistry for a1 subunits in the vessel wall appears to show some endothelial distribution. Is it possible that an endothelial "muscle-type" nAChR is involved in endothelial activation, and expression of adhesion molecules or chemokines? As evidence that there is a role for an endothelial $\mathrm{nAChR}$ in atherogenesis, a1 silencing strikingly reduced the neovascularization of aortic plaques.

\section{Pathological neovascularization and the endothelial nAChR}

This observation is consistent with the notion that plaque neovascularization is critically involved in plaque progression. In this regard, Judah Folkman's group showed that 
endostatin and other anti-angiogenic agents could block the progression of plaque growth in apolipoprotein (ApoE)-deficient mice ${ }^{14}$. Furthermore, inhibition of plaque angiogenesis reduced macrophage accumulation in the atheroma. In the cholesterol-fed rabbit model, Celletti et al. ${ }^{15}$ found that vascular endothelial growth factor (VEGF) promotes plaque neovascularization and growth. Of relevance to the current paper, nicotine increases plaque progression and neovascularization in the $\mathrm{ApoE}^{-/-}$mouse ${ }^{8}$. This effect of nicotine was independent of plasma lipid values and was blocked by rofecoxib, a known inhibitor of angiogenesis. At clinically relevant concentrations, nicotine increases endothelial cell proliferation, migration and capillary-like network formation in vitro. This effect of nicotine (or endogenous acetylcholine) on endothelial cells appears to be largely mediated by the homomeric a 7-nAChR. Pharmacological antagonism (by alpha-bungarotoxin), genetic knockout, or siRNA knockdown of the a 7-nAChR significantly inhibits nicotine-induced activation of the endothelial cell and angiogenic processes ${ }^{8,13}$. It is possible that the reagents used in this study (the a1-siRNA and a 1-subunit antibodies) had some crossreactivity for the endothelial a 7-nAChR. Alternatively, there may be an important role for the "muscle-type" nAChR in endothelial activation.

\section{Exploring the role of the $\mathrm{nAChR}$ in atherosclerosis}

A number of interesting questions are raised by this article. Firstly, is there really a "muscle type" nAChR expressed by any cells in the vessel wall or atherosclerotic plaque? As previously mentioned, in the neuromuscular junction of the adult, these heteromeric receptors consist of $\beta 1, \delta$, and $\varepsilon$ subunits as well as a 1 subunits. Although the presence of the a 1 subunit is consistent with the existence of a vascular "muscle-type" receptor, it is also possible that there is an atypical configuration of a 1-containing nAChRs in the plaque cells. Alternatively, given the notorious cross-reactivity of the antibodies against nAChR subunits, is it possible that another nAChR subunit (e.g. the a 7) is involved. Although specificity should be possible with siRNA silencing, it was not documented in this paper that the silencing was specific to the a 1 subunit.

Much more needs to be understood regarding the function and signaling of nAChRs on the individual cell types contributing to plaque formation. The investigators provide some evidence in supplementary data suggesting that the a 1 containing nAChR mediates proliferation and migration of vascular smooth muscle cells. This is consistent with prior work showing that nicotine can induce the elaboration of fibroblast growth factor and metalloproteinase by vascular smooth muscle cells ${ }^{16}$. On immune cells, these investigators have previously shown that the a 1 subunit is expressed on macrophages, and its expression is linked to macrophage calpain activity and inflammation. On the other hand, it is also known that acetylcholine stimulates a 7 -nAChRs expressed by macrophages ${ }^{17,18}$. Stimulation of this receptor down-regulates proinflammatory cytokine synthesis, and prevents inflammation in animal models of sepsis. The macrophage a 7-nAChR is a critical element in the anti-inflammatory effects of vagus nerve stimulation.

What is the mechanism by which the a 1 subunit becomes upregulated in the atherosclerotic vessel wall? What is the endogenous ligand, and what cells are producing it? Acetylcholine is the classical endogenous agonist of the nAChRs. Of note, acetylcholine is synthesized and stored in endothelial cells, indicating that it might act as an autocrine factor in the vascular system ${ }^{19-21}$. Other potential nAChR agonists include choline, and the peptides SLURP-1 and -2 (lymphocyte antigen 6/urokinase-type plasminogen activator receptor related protein-1 and -2$)^{22}$. The SLURP peptides are allosteric modulators of the nAChRs. Whether these peptides are expressed in the vessel wall, or upregulated in atherosclerosis, is unknown. 
What are the clinical ramifications of this work? Recent genomic evidence indicates that a sequence variant in the cluster of genes on chromosome 15 that encode nicotinic acetylcholine receptors is associated with increased risk of peripheral arterial disease ${ }^{23}$. Although this effect may be mediated through increased nicotine dependency, it is also possible that this genetic variation affects the vascular response to nicotine. Finally, if nicotine itself is involved in the progression of atherosclerosis, what ramifications does this have for nicotine replacement therapies (NRTs) for smokers? On Oct 27 2010, the FDA held a public workshop to discuss the risks and benefits of approving long-term use of NRT (ie. beyond the current approved maximum period of 12 weeks). This workshop revealed that, whereas short-term use of NRTs has been shown to be safe and effective in tobacco cessation, there are little clinical data on the safety and efficacy of long-term use of NRTs. Taken together with other pre-clinical research, the current study suggests that nicotine itself may accelerate atherosclerotic disease. Until clinical data are available on long-term use of nicotine, the astute clinician may wish to substitute other approaches toward tobacco cessation if short-term use of nicotine fails.

\section{Acknowledgments}

This work was supported in part by grants from the National Institutes of Health (RC2HL103400, 1U01HL100397 and K12 HL087746), and by the Tobacco Related Disease Research Program of the University of California (18XT-0098)

\section{References}

1. Benowitz NL. Cigarette smoking and cardiovascular disease: pathophysiology and implications for treatment. Prog Cardiovasc Dis. 2003; 46:91-111. [PubMed: 12920702]

2. Heiss C, Amabile N, Lee AC, Real WM, Schick SF, Lao D, Wong ML, Jahn S, Angeli FS, Minasi P, Springer ML, Hammond SK, Glantz SA, Grossman W, Balmes JR, Yeghiazarians Y. Brief secondhand smoke exposure depresses endothelial progenitor cells activity and endothelial function: sustained vascular injury and blunted nitric oxide production. Journal of the American College of Cardiology. 2008; 51:1760-1771. [PubMed: 18452782]

3. Flouris AD, Vardavas CI, Metsios GS, Tsatsakis AM, Koutedakis Y. Biological evidence for the acute health effects of secondhand smoke exposure. American journal of physiology. 2009; 298:L3L12. [PubMed: 19767410]

4. Prefontaine D, Morin A, Jumarie C, Porter A. In vitro bioactivity of combustion products from 12 tobacco constituents. Food Chem Toxicol. 2006; 44:724-738. [PubMed: 16324776]

5. Lindstrom J. Neuronal nicotinic acetylcholine receptors. Ion Channels. 1996; 4:377-450. [PubMed: 8744214]

6. Changeux JP. Thudichum Medal Lecture. The acetylcholine receptor: a model for allosteric membrane proteins. Biochemical Society transactions. 1995; 23:195-205. [PubMed: 7545603]

7. Conti-Tronconi BM, McLane KE, Raftery MA, Grando SA, Protti MP. The nicotinic acetylcholine receptor: structure and autoimmune pathology. Critical reviews in biochemistry and molecular biology. 1994; 29:69-123. [PubMed: 8026215]

8. Heeschen C, Jang JJ, Weis M, Pathak A, Kaji S, Hu RS, Tsao PS, Johnson FL, Cooke JP. Nicotine stimulates angiogenesis and promotes tumor growth and atherosclerosis. Nat Med. 2001; 7:833839. [PubMed: 11433349]

9. Heeschen C, Weis M, Aicher A, Dimmeler S, Cooke JP. A novel angiogenic pathway mediated by non-neuronal nicotinic acetylcholine receptors. The Journal of clinical investigation. 2002; 110:527-536. [PubMed: 12189247]

10. Villablanca AC. Nicotine stimulates DNA synthesis and proliferation in vascular endothelial cells in vitro. J Appl Physiol. 1998; 84:2089-2098. [PubMed: 9609804]

11. Macklin KD, Maus AD, Pereira EF, Albuquerque EX, Conti-Fine BM. Human vascular endothelial cells express functional nicotinic acetylcholine receptors. The Journal of pharmacology and experimental therapeutics. 1998; 287:435-439. [PubMed: 9765366] 
12. Richman DP, Arnason BG. Nicotinic acetylcholine receptor: evidence for a functionally distinct receptor on human lymphocytes. Proc Natl Acad Sci USA. 1979; 76:4632-4635. [PubMed: 291991]

13. Wu JC, Chruscinski A, De Jesus Perez VA, Singh H, Pitsiouni M, Rabinovitch M, Utz PJ, Cooke JP. Cholinergic modulation of angiogenesis: role of the 7 nicotinic acetylcholine receptor. J Cell Biochem. 2009; 108:433-446. [PubMed: 19623583]

14. Moulton KS, Heller E, Konerding MA, Flynn E, Palinski W, Folkman J. Angiogenesis inhibitors endostatin or TNP-470 reduce intimai neovascularization and plaque growth in apolipoprotein Edeficient mice. Circulation. 1999; 99:1726-1732. [PubMed: 10190883]

15. Celletti FL, Hilfiker PR, Ghafouri P, Dake MD. Effect of human recombinant vascular endothelial growth factor165 on progression of atherosclerotic plaque. Journal of the American College of Cardiology. 2001; 37:2126-2130. [PubMed: 11419898]

16. Carty CS, Soloway PD, Kayastha S, Bauer J, Marsan B, Ricotta JJ, Dryjski M. Nicotine and cotinine stimulate secretion of basic fibroblast growth factor and affect expression of matrix metalloproteinases in cultured human smooth muscle cells. J Vase Surg. 1996; 24:927, 934. discussion 934-925.

17. Wang H, Yu M, Ochani M, Amelia CA, Tanovic M, Susarla S, Li JH, Yang H, Ulloa L, Al-Abed Y, Czura CJ, Tracey KJ. Nicotinic acetylcholine receptor alpha7 subunit is an essential regulator of inflammation. Nature. 2003; 421:384-388. [PubMed: 12508119]

18. Huston JM, Ochani M, Rosas-Ballina M, Liao H, Ochani K, Pavlov VA, Gallowitsch-Puerta M, Ashok M, Czura CJ, Foxwell B, Tracey KJ, Ulloa L. Splenectomy inactivates the cholinergic antiinflammatory pathway during lethal endotoxemia and polymicrobial sepsis. J Exp Med. 2006; 203:1623-1628. [PubMed: 16785311]

19. Wessler I, Kirkpatrick CJ, Racke K. The cholinergic 'pitfall': acetylcholine, a universal cell molecule in biological systems, including humans. Clinical and experimental pharmacology \& physiology. 1999; 26:198-205. [PubMed: 10081614]

20. Arredondo J, Chernyavsky AI, Jolkovsky DL, Pinkerton KE, Grando SA. Receptor-mediated tobacco toxicity: alterations of the NF-kappaB expression and activity downstream of alpha7 nicotinic receptor in oral keratinocytes. Life sciences. 2007; 80:2191-2194. [PubMed: 17291542]

21. Kawashima K, Oohata H, Fujimoto K, Suzuki T. Extraneuronal localization of acetylcholine and its release upon nicotinic stimulation in rabbits. Neuroscience letters. 1989; 104:336-339. [PubMed: 2812548]

22. Moriwaki Y, Yoshikawa K, Fukuda H, Fujii YX, Misawa H, Kawashima K. Immune system expression of SLURP-1 and SLURP-2, two endogenous nicotinic acetylcholine receptor ligands. Life sciences. 2007; 80:2365-2368. [PubMed: 17286989]

23. Thorgeirsson TE, Geller F, Sulem P, Rafnar T, Wiste A, Magnusson KP, Manolescu A, Thorleifsson G, Stefansson H, Ingason A, Stacey SN, Bergthorsson JT, Thorlacius S, Gudmundsson J, Jonsson T, Jakobsdottir M, Saemundsdottir J, Olafsdottir O, Gudmundsson LJ, Bjornsdottir G, Kristjansson K, Skuladottir H, Isaksson HJ, Gudbjartsson T, Jones GT, Mueller T, Gottsater A, Flex A, Aben KK, de Vegt F, Mulders PF, Isla D, Vidal MJ, Asin L, Saez B, Murillo L, Blondal T, Kolbeinsson H, Stefansson JG, Hansdottir I, Runarsdottir V, Pola R, Lindblad B, van Rij AM, Dieplinger B, Haltmayer M, Mayordomo JI, Kiemeney LA, Matthiasson SE, Oskarsson H, Tyrfingsson T, Gudbjartsson DF, Gulcher JR, Jonsson S, Thorsteinsdottir U, Kong A, Stefansson K. A variant associated with nicotine dependence, lung cancer and peripheral arterial disease. Nature. 2008; 452:638-642. [PubMed: 18385739] 